Magdalena Ciechowska*

ORCID: 0000-0001-6811-482X

Anna Walulik**

ORCID: 0000-0002-5607-6974

Kraków, Poland

\title{
Integral Upbringing in the Perspective of Pedagogical Qualitative Research
}

\section{Wychowanie integralne w perspektywie jakościowych badan pedagogicznych}

\begin{abstract}
Summary: The article is aimed at showing the integral upbringing and its role in the pedagogical qualitative research. This kind of upbringing as an object of the pedagogical research at the same time has an impact on the subject of research - the researcher and the researched. It comes to it through the authenticity of form-teacher realizing one of its tasks - to know the pupil - the researched. If such an upbringing activity pursues to the integral development of a person in the atmosphere of mutual respect and dignity, so analogically in the qualitative research the integrity between

* Magdalena Ciechowska PhD - adjunct in the Department of Andragogy and Pedagogical Axiology at Jesuit University Ignatianumin Cracow. Correspondence: Akademia Ignatianum w Krakowie, Instytut Nauk o Wychowaniu, ul. Kopernika 26, 31-501 Kraków, Poland; e-mail: magdalena.ciechowska@ignatianum.edu.pl.

** S. PhD hab. Anna Walulik, prof. of Jesuit University Ignatianum in Cracow, Head of Department of Andragogy and Pedagogical Axiology in the Institute of Educational Sciences in the Faculty of Pedagogy in Jesuit University Ignatianum in Cracow. Correspondence: Akademia Ignatianum w Krakowie, Instytut Nauk o Wychowaniu, ul. Kopernika 26, 31-501 Kraków, Poland; e-mail: anna.walulik@ignatianum.edu.pl.
\end{abstract}


the researcher and the researched takes place. This integrity is shown in two aspects: the research paradigm and research methods sensitive to a person.

Keywords: integrity; integral upbringing; qualitative research.

Streszczenie: Artykuł ma na celu ukazanie wychowania integralnego i jego roli w jakościowych badaniach pedagogicznych. Wychowanie to, będąc przedmiotem badań pedagogicznych, jednocześnie oddziałuje na podmioty badania - badacza i badanego. Dochodzi do tego poprzez autentyczność wychowawcy - badacza realizującego jedno ze swoich zadań - poznawanie wychowanka - badanego. Jeśli działaniom wychowawczym przyświeca dążenie do integralnego rozwoju osoby w atmosferze wzajemnego poszanowania i godności, to analogicznie w badaniach jakościowych dochodzi do integralności między badaczem, badanym i wynikami badań. Owa integralność wyraża się w dwóch aspektach: paradygmacie badawczym oraz metodach badawczych wrażliwych na osobę.

Słowa kluczowe: integralność; wychowanie integralne; jakościowe badania pedagogiczne.

More and more often, the appearance of experience in the range of the lack of order of the postmodern world comes from rejecting the explicit principles and creates new tasks or, in other words, challenges for pedagogy. They also refer both to building pedagogical theories and upbringing practice. We think that one of the attempts to put pedagogical thought in order on two levels can focus the reflection on pedagogical situation in the perspective of integrity. The notion "integral upbringing" has become the word 'picklock', in searching for new recipes for efficient upbringing practice, what for the researchers of upbringing this phenomenon means the necessity of working out new concepts and theories.

In this context, the query about the possibility of conducting such pedagogical research seems to be important. This research could integrate the process of upbringing and scientific research. Using personal experiences, both in the range of upbringing and scientific research, we seek the answers to this problem by showing the relation between the idea of integral upbringing and qualitative pedagogical research. We analyse them in three areas: the acknowledged system of values, the person of form-teacher/researcher and the pupil/the researched. 


\section{Integral upbringing - the most important assumptions seen from the perspective of pedagogical qualitative research}

The main target of qualitative pedagogical research is getting to know the surrounding reality and further - its change, what is particularly seen in the case of the action research. Owing to it, the good that is the quality of pedagogical research has the nature of active good ${ }^{1}$. Nowadays, while discussing the meanings, the need to explicate the emerging good becomes crucial.

The concept of integral upbringing indicates the complex approach to a pupil without negating any of the elements of his/her humanity, be they physical, psychical or spiritual. Zbigniew Formella shows that integral upbringing covers the structures of process of upbringing understood integrally as a homogenous entity that cannot be reduced to functioning only particular elements ${ }^{2}$. Indeed, Zbigniew Marek notices that integral upbringing focuses on a man who becomes its subject, refers to such educative circles which inspire cooperation in creating a new (better) reality ${ }^{3}$. While thinking about the integral upbringing, pedagogues concentrate primary on the pupil, then on pedagogical theories and concepts. Thus, man and his integral development become the central assumption of integral upbringing.

The term integral here refers to the processes of upbringing; first of all, it is a necessity to refer to the word integrity which, in the dictionary's definition, means the process of creating unity from elements ${ }^{4}$. Seeing integrity in terms of the person of pupil and his/her development, we consider the complete development in which any aspect of humanity appears crucial. Moreover, from such thinking emerges the additive quality of integral upbringing that Zbigniew Marek exposes as the basis of development of the person ${ }^{5}$.

1 Tadeusz Pilch, Spory o szkołę (Warszawa: Wydawnictwo Akademickie Żak, 1999), 160.

2 Zbigniew Formella, ,Wychowanie integralne w skautingu. Aktualność propozycji”, in: Pedagogika chrześcijańska. Tradycja. Wspótczesność. Nowe wyzwania, eds. Jarosław Michalski, Aldona Zakrzewska (Toruń: Wydawnictwo Adam Marszałek, 2010), 406-407.

3 Zbigniew Marek, „Wychowanie integralne podstawą rozwoju osoby”, Edukacja Elementarna w Teorii i Praktyce 12 (2007): 33.

${ }^{4}$ Stownik Języka Polskiego, https://sjp.pwn.pl/sjp/integracja;2561723.html [access: 22.02.2018].

5 Marek, „Wychowanie”, 31. 
Under this understanding, integral development does not mean the development coming from only summing the change of particular aspects, but points at its synergistic character ${ }^{6}$. The only holistic perception of pupil and care of any aspect of his/her development will lead to success understood as a new quality of life.

Analysing understanding the integral development, one cannot forget about the form-teacher and integration in reference to his/her person. To realise the process of integral upbringing, he/she has first to become a mature form-teacher, whose positive acts are coherent. Fulfillment of this condition requires an appropriate pedagogue education, whose fundamental process will mean the formation of the individual in question - the pedagogue. Maria Szymańska states that what is hidden within the term 'formation' goes further by understanding it only in terms of upbringing or even self-upbringing ${ }^{7}$. In this context, the following queries about the processes of a pedagogue's education seem justified: Do the curricula of pedagogue education comply with such requirements? Does the complex development of a form-teacher undergo the highest care while constructing the curricula on academic level, or is the emphasis of such a composition of subjects that equips the student in an appropriate knowledge and skills laid on?

A reply to these questions is certainly not unambiguous. It may be that the people responsible for constructing such curricula engage in a peculiar struggle between exterior requirements, a quantity of hours, etc. and assumptions of humanistic paradigm of students' education. Nevertheless, teachers notice that there is a need to reply to an incomplete, insufficient pedagogues' education. In the context of discussion upon integration, seeking a new form of a pedagogue's education can be meaningful, particularly if it becomes the process of creative transformation ${ }^{8}$, leading pedagogue to the mature, holistic look at self, pupil and the process of upbringing.

All in all, the integration in pedagogy can be referred to three elements of upbringing: pupil, form-teacher and the process of upbringing. This conception is the consequence of analyses based on humanistic paradigms, par-

${ }^{6}$ Anna Walulik, Moderacyjne i synergiczne kształtowanie dorosłości. Propozycja typologii modeli znaczeń wiedzy religijnej na przykładzie Korespondencyjnego Kursy Biblijnego (Kraków: WSF-P „Ignatianum”, WAM, 2011).

${ }^{7}$ Maria Szymańska, Transformative creativity in teacher formation: a pedagogical approach (Kraków: AIK, WAM, 2017).

${ }^{8}$ Ibidem. 
ticularly the synergic - participative and subject-participative ones ${ }^{9}$. They are the foundation of qualitative pedagogical research upon the integral upbringing. It means that they cannot be indifferent to the requirement of integration referring to the particular elements of research: the researched one, researcher and the process of research. This requirement of the integration can be referred to the "methodology of pedagogy that is humanistically oriented"10, which is the contradiction of positivistic research assumptions.

Analysing new paradigms and research methods, one can make an attempt to state that in Poland we are the witnesses of the development of "methodology sensitive to a person". It is one that responds to the title of article by Maria Mendel concerning the pedagogy of space and animation sensitive to a space ${ }^{11}$ indicating the fact that the surrounding place is, at the same time, a collection that pedagogues and animators can draw from, but is also the object of influences thanks to which it can change into a better state. This perspective builds the next sensitivity in pedagogy, which means creating the conditions in which the synergy conceiving a new quality of life can be revealed ${ }^{12}$. In the methodology sensitive to the person, the person is in the centre opposite to the positivistic research, where the person is the point over which the research is conducted.

\section{Starting point in the pedagogical qualitative research sensitive to a person - the research paradigm}

The notion of paradigm and its role in the scientific research have been significantly limited in Poland during the period of standards ruling science. This period has changed with the crisis of representation and positivist decline of trust in the knowledge as a form of reflecting reality ${ }^{13}$ and, in con-

9 Maria Szymańska, „Paradygmat podmiotowo-partycypacyjny”, in: Magdalena Ciechowska, Maria Szymańska, Wybrane metody jakościowe w badaniach pedagogicznych, vol. I (Kraków: WAM, AIK, 2017), 42-51.

${ }_{10}$ Metodologia pedagogiki zorientowanej humanistycznie, eds. Dariusz Kubinowski, Marian Nowak (Kraków: Impuls, 2006).

${ }^{11}$ Maria Mendel, „Pedagogika miejsca i animacja na miejsce wrażliwa”, in: Pedagogika miejsca, ed. Maria Mendel (Wrocław: Wydawnictwo Naukowe DSWE TWP, 2006), 21-37.

12 Olaf-Alex Burow, „Synergia jako naczelna zasada pedagogiki humanistycznej”, in: Edukacja alternatywna. Dylematy teorii i praktyki (Kraków: Impuls, 1992), 114-115.

13 Tami Spry, „Performing autoethnography. An embodied moethodological praxis”, Qualitative Inquiry 6 (2001): 706-732. 
sequence, the dynamic development of the qualitative research. In the classical classifications of paradigms, one can find those which go towards the researched or give them the prerogative role in research. Thus, in Yvonny S. Lincoln and Egon G. Guby's classification it is the critical theory, constructivism and participation ${ }^{14}$. According to Gibson Burell and Garetha Morgan ${ }^{15}$, it will be the radical humanism and interpretivism, as well as for John W. Creswell ${ }^{16}$ - constructivism, activism and pragmatism ${ }^{17}$. However, the qualitative research development has resulted in constructing two sequential (mentioned earlier) paradigms, which seem to be the most adequate in searching the relationships between the integral development and qualitative research.

The first one is the synergic-participatory paradigm that has been driven from pedagogy oriented towards humanism by Dariusz Kubinowski. The author thinks that the idiom that reflects the idea of pedagogy as a science is the category "between". He states that pedagogy is located between science, humanities, art, ethics and activity; between theory area and praxis domain, between actuality and potentiality, between philosophy and empirical approach, between description and critics, between diagnosis, prognosis and designing, between experience and imagination, between unity and diversity, between reflection and methodology ${ }^{18}$.

Such a term both provides and demands wide research possibilities. Hence, the synergic-participatory paradigm ${ }^{19}$ outlines broadly the roles of researcher and the researched, based on two pillars: synergy and participation. To make the synergy appear, what means coordination between researcher and the researched, it is necessary to treat the second one as a subject. Then, the participation means two-fold character of participation - on the one hand, the researcher's participation in the life of the researched; on the other hand, the researcher's participation in research and sensitivity to any elements con-

${ }^{14}$ Yvonn S. Lincoln, Egon G. Guba, „Kontrowersje wokoł paradygmatow, sprzeczności i wyłaniające się zbieżności”, in: Metody badań jakościowych, vol. 1, eds. Norman K. Denzin, Yvonna S. Lincoln (Warszawa: PWN, 2009).

15 Gibson Burrell, Gareth Morgan, Sociological paradigms and organizational analysis (London: Heinemann Educational Books, 1979).

${ }^{16}$ John W. Creswell, Projektowanie badań naukowych. Metody jakościowe, ilościowe i mieszane (Kraków: Wydawnictwo UJ, 2013).

17 But this paradigm is typical for research in mixed strategy.

${ }^{18}$ Dariusz Kubinowski, Jakościowe badania pedagogiczne. Filozofia-Metodyka-Ewaluacja (Lublin: Wydawnictwo UMCS, 2010), 98.

${ }^{19}$ Ibidem, 143-150. 
structing the space that it takes place. Therefore, the synergy appears as the derivative of participation. Furthermore, that is why a more accurate name for this paradigm seems to be the participatory-synergic one.

The second paradigm, within which the qualitative pedagogical research are conducted concerning the integral upbringing is the paradigm described Maria Szymańska as subject-participatory ${ }^{20}$. The author specifies some principles that should be taken into consideration by the researcher. They include the elements of freedom, equality, truth, helpfulness, sublimation, prevention, integration and praxis ${ }^{21}$, which are complementary to the principles used in - participatory research, worked out by Jarg Bergold and Stephan Thomas as the principles of democracy, safe space and the principle of defining the grade of participation of research participants' community ${ }^{22}$.

The researcher observing all these principles treats the researched in category of subject, so referring his research to the space of integral upbringing. What is more, treating a pupil as a subject enables the researcher to have a closer look at the pupil's environment. Thanks to it, the researcher can define the principles of the pupil's participation in the research on each stage, what should bring benefits both to the pupil and researcher. One can say that the derivative of these factors is the research synergy which starts between the researcher and the researched. Thanks to it, they can cooperate together in the realisation of research.

Anna Walulik emphasises that we have to do with synergy when the elements constituting the conjoint activity become synchronised and cooperate in a harmonious way. Since it is so dependable of many factors, it is easy to destroy or block it. Thus, in a humanistic perspective, the synergy should be understood as 'added value' which is not created explicitly but reveals as additional element of influence or cooperation between two or more distin-

20 Szymańska, „Paradygmat”, 42-51.

${ }^{21}$ Ibidem, 47-49. The principles of: sublimation, integration and praxis described wider in: Maria Szymańska, „Zasada sublimacji”, in: Mały słownik aksjologiczny, eds. Zdzisław Struzik, Dominika Żukowska-Gardzińska (Warszawa: Wydawnictwo Instytutu Papieża Jana Pawła II: 2013), 298; Maria Szymańska, „Zasada integracji”, in: Mały słownik aksjologiczny, eds. Zdzisław Struzik, Dominika Żukowska-Gardzińska (Warszawa: Wydawnictwo Instytutu Papieża Jana Pawła II: 2013), 290-292; Maria Szymańska, „Zasada praxis”, in: Mały słownik aksjologiczny, eds. Zdzisław Struzik, Dominika Żukowska-Gardzińska (Warszawa: Wydawnictwo Instytutu Papieża Jana Pawła II: 2013), 294.

22 Jarg Bergold, Stephan Thomas, "Participatory research methods: a methodological approach in motion, Forum Qualitative Sozialforschung", Forum: Qualitative Social Research 1 (2012): 242-263. 
guished factors ${ }^{23}$. It is worth noticing that the synergy can take place in different dimensions of the research process, for in each of them a new quality can reveal what is presented beneath.

Fig. 1. Dimensions of the research process used for the synergy arise.

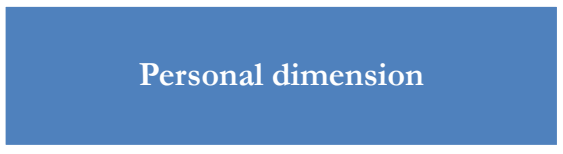

The researcher

(ethics, skills)

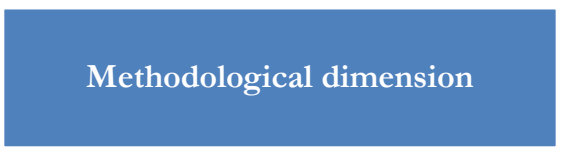

Triangulation in the qualitative research

The researched

(the role assigned by

researcher )

Source: Maria Szymańska, Magdalena Ciechowska, Katarzyna Pieróg, Sylwia Gołąb, Badania $w$ działaniu $w$ praktyce pedagogicznej. Wybrane przykłady (Kraków: AIK, 2018), 195.

For each aspect analysed of integral upbringing in the perspective of qualitative research, the personal dimension has the priority meaning. Owing to the researcher's competencies and his acts of observing ethics both while collecting data, as well as ensuring the quality of research, also designating the appropriate roles to the research and the synergy has the space for arising. The researcher moving in such a dimension of research creates the space for the integral upbringing, in which they will cooperate with the respondents leading to their full development and making this reality the subject of scientific reflection. The researcher will also construct theories or pedagogical concepts.

${ }^{23}$ Anna Walulik, „Pedagodzy - młodzi badacze w przestrzeni podmiotowości, partycypacji i synergii", in: Magdalena Ciechowska, Maria. Szymańska, Wybrane metody jakościowe w badaniach pedagogicznych, vol. I (Kraków: WAM, AIK, 2017), 13; cf. Anna Walulik, Moderacyjne. 


\section{Integral upbringing as a space of the researcher activity in the selected qualitative methods}

The qualitative research abounds in a wide spectrum of the research methods, in which the complex acts performed by positivist researcher from the concept through to the ways of gathering data (techniques) - and the tools used for collecting data and analysis subjugates the choice of the researched. However, one can specify such methods which arise a particular sensitivity of researcher to the person of the researched and his wellbeing. Furthermore, the researcher, respecting one of the paradigms mentioned above, does not leave the researched in uncomfortable for him life situation, but through the results of his research (and in case of the action research also while conducting it) he will make an attempt to change the life circumstances of the researched and influence his behaviour positively. The trust and relationship with the researched fosters it; such methods cover, for example, the case study, action research and autoethnography.

The qualitative case study demands from the researcher deepening into the case of researched. A great number of the types of case study ${ }^{24}$ lead to the conclusion that it is one of the most popular qualitative method. In the qualitative case study, the researcher's acts of doing are coincident with the form-teacher's acts of doing who deploys the concept of integral upbringing into life through holistic and at the same time deep viewing a concrete case. Here, there is no place for accidental, non-checked information and the research accuracy is fostered by the deployment of techniques triangulation.

One should emphasise that those researched are often people who allow such behaviour to appear in their lives in a way that is not accepted by the researcher, meaning that it affects the good of other humans ${ }^{25}$. Hence, in this case, the researcher should conduct the research according to one of the principle of personalism, which underlines the necessity of detaching the man from his activity ${ }^{26}$ and make assumptions as the form-teacher assumes that his pupil is good.

${ }^{24}$ M. Ciechowska based on typology by R.C. Bogdan i S.K. Biklen distinguishes eight such types because of the object of research: Magdalena Ciechowska, „Studium przypadku”, in: Magdalena Ciechowska, Maria Szymańska, Wybrane metody jakościowe w badaniach pedagogicznych, vol. I (Kraków: WAM, AIK, 2017), 171-175.

${ }^{25}$ More about it in the next part of this article.

${ }^{26}$ Karol Wojtyła, Osoba i czyn (Kraków: Polskie Wydawnictwo Teologiczne, 1985). 
Another method, action research, requires a particular attention in the context of relations which take place between the integral development and the pedagogical qualitative research. Its exceptional dimension results from the fact that the change can appear even on the first step of research, through implementation of the following steps of the method in practice $^{27}$, in a way that is accepted by the researched. The researcher who serves the researched with his competencies hence recognises the needs of the researched. What is more, in the scope of this method the researcher can influence a community, and in the scope of participation active research also the community in which he acts. It makes people gather around the problems in order to identify and solve them, what results in building the cooperation. It tightens the bonds and enlarges mutual trust, uniting the community that makes research and acts in what results in democratisation, building relationships are also reciprocal ${ }^{28}$.

Particular role in the integral upbringing can perform the auto-ethnography as the method in which the researcher makes the research upon self, own emotions, behaviour and thoughts in the perspective of the culture that surrounds him. This is the particular case when the researcher within the research means, simultaneously, the person researched. Owing to the auto-ethnography, the researcher forming the teacher can experience self-formation and feel how to be the researched person. These experiences can help understand the sensitivity one should possess, while cooperating with the researched so that they could disclose often difficult and painful information to the researcher.

The formation takes place here in two spaces - one is the space of collecting data, the second one is the function that the conducted research carries. Gathering data is varied and innovative in comparison with other techniques ${ }^{29}$ which allows the researcher to discover many crucial matters forming him

${ }^{27}$ Zob: Maria Szymańska, „Badania w działaniu”, in: Magdalena Ciechowska, Maria Szymańska, Wybrane metody jakościowe w badaniach pedagogicznych, vol. I (Kraków: WAM, AIK, 2017), 248-255.

${ }_{28}$ Maria Czerepaniak-Walczak, „Badanie w działaniu w kształceniu i doskonaleniu nauczycieli”, Przegląd Badań Edukacyjnych 2 (2014): 185.

${ }^{29}$ Such as, for example, autointerview, autoobservation, or autoethnography essay: Magdalena Ciechowska, „Autoetnografia w badaniach pedagogicznych”, in: Magdalena Ciechowska, Maria Szymańska, Wybrane metody jakościowe w badaniach pedagogicznych, vol. I (Kraków: WAM, AIK, 2017), 213-216. 
and his own, sometimes, hard experiences. The incredibly interesting role of memory is shown in the film The Giver, based on the novel The Giver by Lois Lowrcy ${ }^{30}$. The plot takes place in an idealised, artificially established world by man without suffering, sadness. This state has been achieved thanks to eliminating any otherness and... eliminating emotions and memory. Just our memory, our experience, and emotions accompanying them designate our otherness and uniqueness. Owing to our memory, we keep the continuity of our identity.

Hence, auto-ethnography is the method that enables us to extract this thing which is unique in us and from what we can offer others. The authors of diploma projects working with this method underline that, owing to it, they found the value of thing that they had experienced earlier (although sometimes there were events) and their role in becoming a pedagogue is more mature and more conscious about the experiences having impact on their formation. They have become the pedagogues whose life fates were not accidental as, thanks to concrete stack of experiences, they can help persons similar to them ${ }^{31}$.

Another space in which the formation of researcher appears are the unique functions ${ }^{32}$ to which the autoethnograpy brings fruits. We can divide them into those showing the individual dimension and so having significant meaning for the researcher. The functions comprise of the cognitive, therapeutic and educational. The second dimension of function pertains to its wider influence, entailing that this dimension can be named as communitybased. Here, it is considered the democratic and emancipator function.

It is worth noticing that autoethnography is not only concerned with individual research - it can be built by two researchers (duoethnography) or the whole group (community - based or collaborative autoethnography). Hence, each type of the autoethnography research fosters the construction of the qualitative researcher's identity, which is incredibly important in his work of upbringing.

${ }^{30}$ The Giver (2014, director. Philip Noyce) based on the novel The Giver by Lois Lowrcy (Kraków: Galeria Książki, 2014).

31 The author's own archive and the diploma projects written with the use of the authoethnograpy metod - The Archive of Jesuit University Ignatianum in Cracow.

32 The function division: Ciechowska, „Autoetnografia”, 219-222. 


\section{The meaning of integral upbringing in a pedagogical qualitative research}

The phenomenon of integral upbringing is the specific subject of this research because it demands integrity of elements of the research process. Reflection upon it enforces a research approach making reference to humanistic paradigms and so to qualitative research, as we question whether or not it is possible to research the process of upbringing in the peer group or functioning of a child without looking in a holistic way at the child's development, using non-idiomatic research methods, and finally describing such phenomena in the statistical data?

Discourse on these possibilities in pedagogy is called by Dariusz Kubinowski humanistic quantophrenia ${ }^{33}$. In this context, one can acknowledge that integral development is not the research object given to pedagogues (for they deal with it), but one that is ordered. The right realisation of the integral development idea demands not only the integration of all the developmental spheres, but also requires all the elements of reflection to engage with it in the shape of research process. Such integrity in the pedagogical qualitative research guarantees authenticity of the cognitive process which simultaneously has the power of indication, and in a further step of implementing the changes that optimise the process of upbringing (Figure 1).

This scheme illustrates the meaning of integral development in the pedagogical qualitative research and how it affects the particular elements of the research process. The researcher, who poses the goal of getting the knowledge of the part of reality assigned by the integral development, prepares the adequate research process to do it. It concerns both himself (the choice of the research paradigm, adjusting the research methods, techniques, and tools) and the researched. This last aspect of participatory research is expressed through obtaining the conscious acceptance of the research participation by

33 This term created by the author was based on the term quantophrenia introduced to sociology by Pitirim Sorokin, which means the positivist tendency for measuring everything [zob. Dariusz Kubinowski, „Metodologia spod znaku $\chi 2$ a humanistyczna tożsamość pedagogiki", in: Metodologiczne problemy tworzenia wiedzy w pedagogice. Oblicza akademickiej praktyki, eds. Jacek Piekarski, Danuta Urbaniak-Zając, Krzysztof J. Szmidt (Kraków: Impuls, 2010), 80; Pitirim A. Sorokin, Fads and foibles in modern sociology (Chicago: Henry Regnery Co., 1956); Stanisław Ossowski, O osobliwościach nauk społecznych (Warszawa: PWN, 2001). 
the researched or, in the case of their underage state, the permission of their formal caregiver ${ }^{34}$. Furthermore, the pedagogical qualitative research applies an explicit set of ethics while conducting the research as the central point; as a consequence, the dialogue with the researched also comprises of their inclusion into research and certainly takes into consideration the age and psychophysical possibilities of the researched. The researcher can also verify the research goals because of the remarks given by the researched, what is characteristic for this strategy.

Fig. 2. Integral development in the process of pedagogical qualitative research

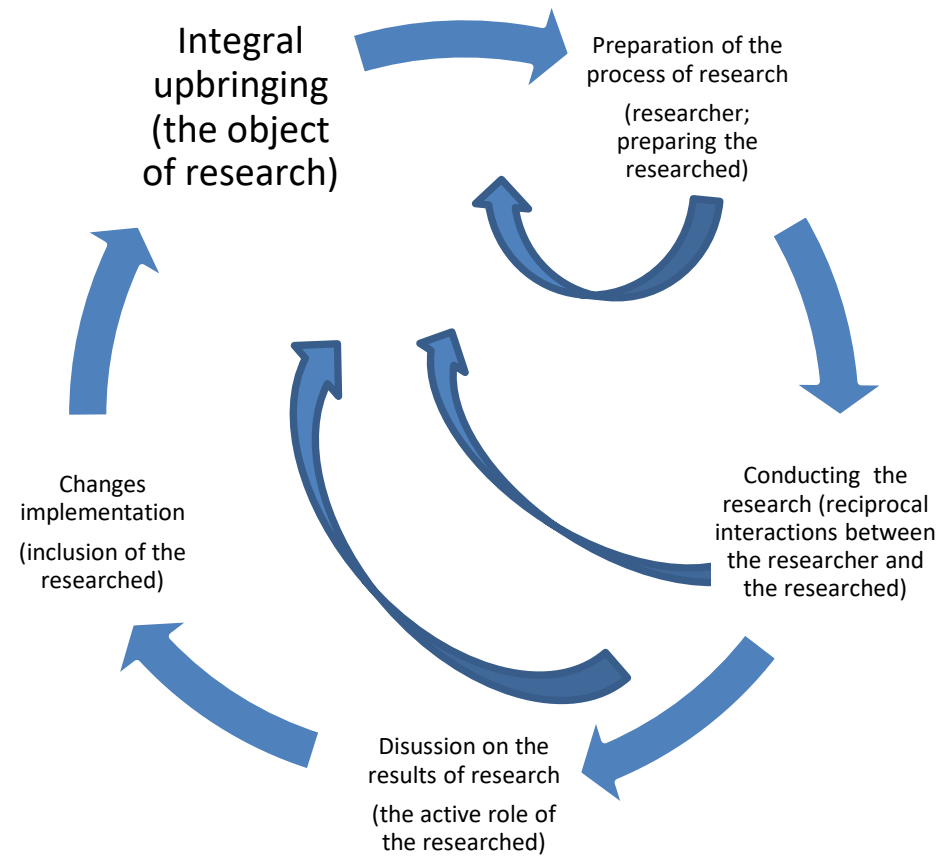

Source: authors of the article.

${ }^{34}$ More about intricacies concerning ethics in the pedagogical qualitative research with the references to the adequate subject literature in: Magdalena Ciechowska, „Etyczne aspekty jakościowych badań pedagogicznych”, in: Magdalena Ciechowska, Maria Szymańska, Wybrane metody jakościowe w badaniach pedagogicznych, vol. I (Kraków: WAM, AIK, 2017). 
Ethics performs a great role at each step of the qualitative research starting with the stage of conceptualisation, then collecting the field data and ensuring the quality of research - for example, with the communicative validation as the last final stage. This indicates the standards of reciprocal interactions between the researcher and the researched in the research trajectory and at the stage of disclosing the results, which should be open and discussed with the researched.

The final effect entails the optimisation of the processes with the objectives of making the world better, change in the behaviour, etc. However, everything should be in accordance with the importance of each aspect crucial for the researched (spirituality, intellect, psyche, physicality) understood as good and a crucial one for them. Thanks to seeing the researched person as an integral unity, the researcher is able to choose and deploy the desirable changes into life, thus looking at the pupil's good in a long-term perspective. In this case, the pupil takes the role of the researched. All the researcher's acts of doing have to be in line with the agreement made by the researched, in accordance with the principle of respecting their participation in the research.

\section{Conclusion}

Looking holistically at the process presented above, one may notice reciprocal connection between the integral upbringing as the object of the research and its particular elements and the processes of scientific research. The researcher/form-teacher who is interested in conducting the research on integral development has to undertake appropriate steps to be well prepared for them, such as deepening his or her own knowledge, taking a concrete paradigm for granted and acting in an appropriate way with the research participants so creates the space for integral development.

\section{References}

Bergold, Jarg, Stephan Thomas. „Participatory research methods: a methodological approach in motion, Forum Qualitative Sozialforschung", Forum: Qualitative Social Research 1 (2012): 242-263.

Burow, Olaf-Alex. „Synergia jako naczelna zasada pedagogiki humanistycznej”. In: Edukacja alternatywna. Dylematy teorii i praktyki, ed. Bogusław Śliwerski, 91-105. Kraków: Impuls, 1992. 
Burrell, Gibson, Gareth Morgan. Sociological paradigms and organizational analysis. London: Heinemann Educational Books, 1979.

Ciechowska, Magdalena. „Studium przypadku”. In: Magdalena Ciechowska, Maria Szymańska, Wybrane metody jakościowe w badaniach pedagogicznych, vol. I, 165-196. Kraków: WAM, AIK, 2017.

Ciechowska, Magdalena. „Autoetnografia w badaniach pedagogicznych”. In: Magdalena Ciechowska, Maria. Szymańska, Wybrane metody jakościowe w badaniach pedagogicznych, vol. I, 197-224. Kraków: WAM, AIK, 2017.

Creswell, John W. Projektowanie badań naukowych. Metody jakościowe, ilościowe i mieszane. Kraków: Wydawnictwo UJ, 2013.

Czerepaniak-Walczak, Maria. „Badanie w działaniu w kształceniu i doskonaleniu nauczycieli”. Przegląd Badań Edukacyjnych 2 (2014): 181-184.

Formella, Zbigniew. „Wychowanie integralne w skautingu. Aktualność propozycji”. In: Pedagogika chrześcijańska. Tradycja. Wspótczesność. Nowe wyzwania, eds. Jarosław Michalski, Aldona Zakrzewska, 404-421. Toruń: Wydawnictwo Adam Marszałek, 2010.

Kubinowski, Dariusz. „Metodologia spod znaku $\chi 2$ a humanistyczna tożsamość pedagogiki”. In: Metodologiczne problemy tworzenia wiedzy w pedagogice. Oblicza akademickiej praktyki, eds. Jacek Piekarski, Danuta Urbaniak-Zając, Krzysztof J. Szmidt, 79-89. Kraków: Impuls, 2010.

Kubinowski, Dariusz. Jakościowe badania pedagogiczne. Filozofia - MetodykaEwaluacja. Lublin: Wydawnictwo UMCS, 2010.

Lincoln, Yvonn S., Egon G. Guba. „Kontrowersje wokół paradygmatów, sprzeczności i wyłaniające się zbieżności”. In: Metody badań jakościowych, eds. Norman K. Denzin, Yvonna S. Lincoln, vol. 1, 281-314. Warszawa: PWN, 2009.

Marek, Zbigniew. „Wychowanie integralne podstawą rozwoju osoby”. Edukacja Elementarna w Teorii i Praktyce 12 (2007): 31-47.

Mendel, Maria. „Pedagogika miejsca i animacja na miejsce wrażliwa”. In: Pedagogika miejsca, ed. Maria Mendel, 21-37. Wrocław: Wydawnictwo Naukowe DSWE TWP 2006.

Metodologia pedagogiki zorientowanej humanistycznie, ed. Dariusz Kubinowski, Marian Nowak. Kraków: Impuls, 2006.

Ossowski, Stanisław. O osobliwościach nauk społecznych. Warszawa: PWN, 2001.

Pilch, Tadeusz. Spory o szkołę. Warszawa: Wydawnictwo Akademickie Żak, 1999.

Sorokin, Pitirim A. Fads and foibles in modern sociology. Chicago: Henry Regnery Co., 1956.

Spry, Tami. "Performing autoethnography. An embodied moethodological praxis". Qualitative Inquiry 6 (2001): 706-732. 
Szymańska, Maria. „Zasada sublimacji”. In: Mały stownik aksjologiczny, eds. Zdzisław Struzik, Dominika Żukowska-Gardzińska, 298. Warszawa: Wydawnictwo Instytutu Papieża Jana Pawła II, 2013.

Szymańska, Maria. „Zasada integracji”. In: Maty słownik aksjologiczny, eds. Zdzisław Struzik, Dominika Żukowska-Gardzińska, 290-292. Warszawa: Wydawnictwo Instytutu Papieża Jana Pawła II: 2013.

Szymańska, Maria. „Zasada praxis”. In: Mały stownik aksjologiczny, eds. Zdzisław Struzik, Dominika Żukowska-Gardzińska, 294. Warszawa: Wydawnictwo Instytutu Papieża Jana Pawła II: 2013.

Szymańska, Maria, Magdalena Ciechowska, Katarzyna Pieróg, Sylwia Gołąb. Badania w działaniu w praktyce pedagogicznej. Wybrane przykłady. Kraków: Wydawnictwo Naukowe AIK, 2018.

Szymańska, Maria. „Paradygmat podmiotowo-partycypacyjny”. In: Magdalena Ciechowska, Maria Szymańska, Wybrane metody jakościowe w badaniach pedagogicznych, vol. I, 42-50. Kraków: WAM, AIK, 2017.

Szymańska, Maria. „Badania w działaniu”. In: Magdalena Ciechowska, Maria Szymańska, Wybrane metody jakościowe w badaniach pedagogicznych, vol. I, 225-272. Kraków: WAM, AIK, 2017.

Szymańska, Maria. Transformative creativity in teacher formation. A pedagogical approach. Kraków: WAM, AIK, 2017.

Walulik, Anna. „Pedagodzy - młodzi badacze w przestrzeni podmiotowości, partycypacji i synergii”. In: Magdalena Ciechowska, Maria Szymańska, Wybrane metody jakościowe w badaniach pedagogicznych, vol. I, 7-18. Kraków: WAM, AIK, 2017.

Walulik, Anna. Moderacyjne i synergiczne ksztaltowanie dorostości. Propozycja typologii modeli znaczeń wiedzy religijnej na przykładzie Korespondencyjnego Kursu Biblijnego. Kraków: WSFP „Ignatianum”, WAM: 2011.

Wojtyła, Karol. Osoba i czyn. Kraków: Polskie Wydawnictwo Teologiczne, 1985. 